DOI: https://doi.org/10.15407/techned2021.05.027

\title{
COMPARATIVE ANALYSIS OF MAGNETIC SYSTEMS OF PERMANENT MAGNET MOTORS FOR TRAM
}

\author{
V.V. Grebenikov", R.V. Gamaliia**, S.A. Dadychyn \\ Institute of Electrodynamics of National Academy of Sciences of Ukraine \\ Pr. Peremohy, 56, Kyiv, 03057, Ukraine, e-mail: elm1153@gmail.com
}

A numerical study of eight configurations of magnetic systems of electric motors with permanent magnets for driving a
tram was carried out. The permanent magnet electric motor can be used as a high-speed electric drive to replace the
existing DC electric drive of a tram, and as a low-speed gearless electric drive of a new generation tram. The most
promising configurations of magnetic systems of electric motors with permanent magnets for tram drive have been
determined. By varying the geometrical and winding parameters of each of the investigated models of electric motors,
the mechanical characteristics are determined, at which the given torque and power are achieved in the entire range of
the rotor speed. Also, a thermal calculation was performed taking into account the urban driving cycle of high-speed
electric motors with air cooling by a fan and low-speed ones in liquid cooling mode. The calculation of the
characteristics of the investigated electric motors was carried out in the Simcentre MotorSolve software package.
References 13, figures 8, tables 3 .

Keywords: numerical modeling, electric motor, permanent magnets, electromagnetic torque, performance characteristics, thermal calculation, electric tram drive.

Introduction. The current level of development of electric motors with permanent magnets and power converters (inverters) allows us to consider them for new promising tram electric drive systems. Currently, most tram cars use DC traction motors with series excitation [1]. This drive generates increased torque at low speed and limited torque at high speed, which ensures the necessary dynamics of the tram. In most cases, one voltage converter drives two motors joined in series. However, a series-excited DC traction motor has several disadvantages. The drive does not fully provide dynamic braking at low tram speed. The presence of a brush assembly reduces the resource and reliability of the engine. Probably, the modernization of the traction drive based on DC motors with series excitation has reached its limit. Further improvement of the tram drive efficiency is possible only with the transition to a new type of drive: asynchronous [2, 3], permanent magnet motors $[4,5]$, etc.

Favorable conditions for the creation of new traction electric drive systems are provided by the availability of modern efficient frequency converters of alternating current (inverters) on the market. Therefore, at present, the $\mathrm{AC}$ traction drive system has become widespread. The traction drive includes a frequency converter (inverter) and an AC motor: asynchronous or permanent magnet motor. The frequency converter (inverter) provides the operation of one or two motors connected in parallel. As an example, we can cite converters (inverters) of the BORDLINE CC400 DC type manufactured by ABB [6]. The AC traction drive increases the efficiency and reliability of the drive.

Permanent magnet motors are one of the most promising for use in traction electric drives. When using liquid cooling, permanent magnet motors provide the highest specific performance (torque and power developed per unit mass of the motor). The small overall dimensions of the permanent magnet electric motor make it possible to use more advanced kinematic diagrams of the tram car driving bogies.

Eventually, a drive system based on a frequency converter (inverter) and a permanent magnet motor can compete with a traditional DC drive system. There are a large number of magnetic system configurations for a permanent magnet traction drive. The advantage of a particular configuration can be determined based on the requirements for the drive, as a rule, these are the overall dimensions of the electric motor and the type of mechanical characteristics depending on the rotor speed [7-9].

(C) Grebenikov V.V., Gamaliia R.V., Dadychyn S.A., 2021

ORCID ID: * https://orcid.org/0000-0002-1114-1218; ** https://orcid.org/0000-0002-5729-7891 
Research purpose. The aim of this work is a comparative analysis of several configurations of the magnetic system of electric motors with permanent magnets in relation to the traction drive of a city tram and an analysis of the advantages and disadvantages of various configurations of the magnetic systems of electric motors. In the course of the study, electric motors with permanent magnets are conventionally divided into two groups: high-speed motors (rated speed $n=1750 \mathrm{rpm}$ ) as a variant of replacing the existing traction electric drive of the tram; low-speed motors $(n=320 \mathrm{rpm})$ for a gearless traction electric drive of perspective low-floor tram models.

The first group of high-speed motors is designed to replace the existing TE-022 DC traction motor of the T-3 tram. In this group, numerical investigations of four configurations of the magnetic system of electric motors with a power of $\mathrm{P}=45 \mathrm{~kW}, \mathrm{n}=1750 \mathrm{rpm}$ were carried out. The second group of low-speed engines is intended for the gearless drive of promising tram models. In this group, four modifications of the magnetic system were also investigated, which have a power of $\mathrm{P}=46 \mathrm{~kW}$ and rated speed $\mathrm{n}=320 \mathrm{rpm}$. The same power of the engines under study is the main criterion for comparing engines of different designs. Permanent magnet motors of each group differ from each other in the configuration of the rotor and stator.

For each of the design options for an electric motor with permanent magnets, a calculation cycle is envisaged in order to find the best option by varying a number of parameters (configuration of the magnetic system of the rotor and stator, winding data, material properties).

Permanent magnet motor as an alternative to the existing TE-022 motor. The existing TE-022 engine of the T-3 tram is a DC motor with series excitation [1]. The main parameters of the TE- 022 engine are as follows: rated power $-45 \mathrm{~kW}$; rated speed $-1750 \mathrm{rpm}$; maximum rotation speed $-4200 \mathrm{rpm}$; rated voltage $-300 \mathrm{~V}$; rated current $-150 \mathrm{~A}$; efficiency $-91 \%$; cooling air consumption $-7.5 \mathrm{~m} 3 / \mathrm{min}$; electric motor weight $-320 \mathrm{~kg}$; length $-683 \mathrm{~mm}$, diameter $-400 \mathrm{~mm}$.

The mechanical characteristics of the TE-022 electric motor are favorable (convenient) for driving a tram. The maximum (starting) torque of the traction electric drive is $\mathrm{M}=650 \mathrm{Nm}$. The maximum torque is limited by the maximum current supplied by the drive control system. Most of the TE-022 traction motor control systems provide a maximum motor current of no more than $300 \mathrm{~A}$. With an increase in the rotational speed, the torque and current of the electric motor decreases and at a rated speed of $n=1750 \mathrm{rpm}$ the electromagnetic torque is $M=260 \mathrm{Nm}$. At the maximum rotational speed $n=4200 \mathrm{rpm}$, the torque is $\mathrm{M}=50 \mathrm{Nm}$. The mechanical characteristic of the permanent magnet motor should be similar to that of the existing TE - 022 motor.

The investigated system of a traction electric drive based on an electric motor with permanent magnets provides for the installation of a converter (inverter) to control one or two motors connected in parallel. The maximum torque of a permanent magnet motor is provided by the maximum output current of the converter (inverter). The permanent magnet motor is cooled by an air cooling system.

All investigated variants of electric motors with permanent magnets have the same outer diameter of the stator magnetic system, and the same electromagnetic loads (current density, magnetic induction value in the stator teeth) are set for all variants. The current density in the windings at the rated speed is assumed to be $\mathrm{J}=4.0 \mathrm{~A} / \mathrm{mm}^{2}$, during start-up $-\mathrm{J}=10 \mathrm{~A} / \mathrm{mm}^{2}$. The magnitude of the magnetic induction in the stator teeth is limited to $\mathrm{B}=2.0 \mathrm{~T}$.

A general view of the design options for the first group of the studied electric motors with permanent magnets with a nominal speed of $n=1750 \mathrm{rpm}$ is shown in Fig. 1. The lower part of this figure shows a general view of the rotor of each of the electric motors. To reduce the cogging torque the rotor poles skew is made by one toothed division [10]. The M1 electric motor is multi-pole. The phase windings of the electric motor are coils that are winded up on the stator teeth (covering the stator teeth), the dimension of stator iron back is smaller than that of the stator of a traditional synchronous motor. There is an optimum ratio between the number of rotor poles and the number of stator teeth that provides the best performance for the motor. High electromagnetic loads are provided in the electric motor: magnetic induction in the air gap and linear current load of the windings. The magnetic flux of the rotor pole is created by magnets with tangential magnetization. By choosing a larger pole height (size of the magnets), it is possible to provide an increased magnetic flux density in the motor gap. The lumped stator winding allows you to increase the size of slots and, accordingly, increase the linear current load of the electric motor. At present, electric motors of this type are produced in series mainly for low-speed gearless electric drives.

The M2 motor uses the traditional design of a permanent magnet synchronous motor, in which the rotor poles are composed of tangentially magnetized prismatic permanent magnets, the stator contains a distributed winding in which the phase coil covers the pole division. The M3 electric motor, in contrast to the 
M2 electric motor, has a rotor with magnets of radial magnetization. To reduce eddy current losses, permanent magnets of rotor poles are divided into 6 parts.

The M4 electric motor has an implicit-pole rotor, which is a package of electrical steel with permanent magnets. The rotor electrical steel package has slots in which permanent magnets are installed. Structurally, all elements of the rotor magnetic circuit are located on the sheet of electrical steel: the north and south poles, the "back" of the rotor poles. The elements of the rotor magnetic circuit are interconnected by thin bridges, which provide a simple technology for manufacturing the rotor. The dimensions of the bridges provide the mechanical strength of the rotor with a slight negative effect on the magnitude of the rotor magnetic flux. There are various options for the configurations of the rotor poles. The skew of the rotor poles is performed by a set of rotor sections shifted relative to each other by a given angle. At present, this design of an electric motor with permanent magnets is one of the most promising for use in electric transport.

\begin{tabular}{|c|c|c|c|c|}
\hline $\mathrm{M} 1$ & $\mathrm{M} 2$ & $\mathrm{M} 3$ & $\mathrm{M} 4$ \\
\hline
\end{tabular}

Fig. 1

For each of the design variants of the permanent magnet electric motor, a calculation cycle was performed. By varying the basic geometrical parameters of the rotor and stator magnetic systems, winding data and the properties of permanent magnets, a search was made for the best option, taking into account the requirements for the drive (the power developed by the motor at a given rotor speed). Comparison of various engine options was carried out at the same electromagnetic loads.

The calculation of the characteristics of electric motors is carried out in the Simcenter MotorSolve package [13], which allows you to set the mode of electric current control of the motor. A sinusoidal form of the supply current is adopted for all motor variants. Magnetic field patterns for the nominal mode of each of the options are shown in Fig. 2. Analyzing the calculation results it should be noted that the maximum magnetic induction in the teeth of the investigated electric motors is as follows: $\mathrm{M} 1-\mathrm{B}_{\mathrm{M} 1 \text { (tooth) }}=1.92 \mathrm{~T}$; $\mathrm{M} 2-\mathrm{B}_{\mathrm{M} 2 \text { (tooth) }}=1.87 \mathrm{~T}$; $\mathrm{M} 3-\mathrm{B}_{\mathrm{M} 3 \text { (tooth) }}=1.86 \mathrm{~T}$; M4 $-\mathrm{B}_{\mathrm{M} 4 \text { (tooth) }}=1.79 \mathrm{~T}$. In the back of the stator, the maximum values of the magnetic induction are as follows: $\left.\mathrm{M} 1-\mathrm{B}_{\mathrm{M} 1 \text { (back) }}\right)=1.48 \mathrm{~T}$; $\mathrm{M} 2-\mathrm{B}_{\mathrm{M} 2 \text { (back) }}=1.82 \mathrm{~T}$; $\mathrm{M} 3-\mathrm{B}_{\mathrm{M} 3 \text { (back) }}=1.93 \mathrm{~T}$; $\mathrm{M} 4-\mathrm{B}_{\mathrm{M} 4 \text { (back) }}=1.79 \mathrm{~T}$. Thus, the dimensions and geometry of the magnetic system are selected in such a way that the condition is fulfilled: the induction in the teeth and back of the stator is limited to $\mathrm{B}=2.0 \mathrm{~T}$.
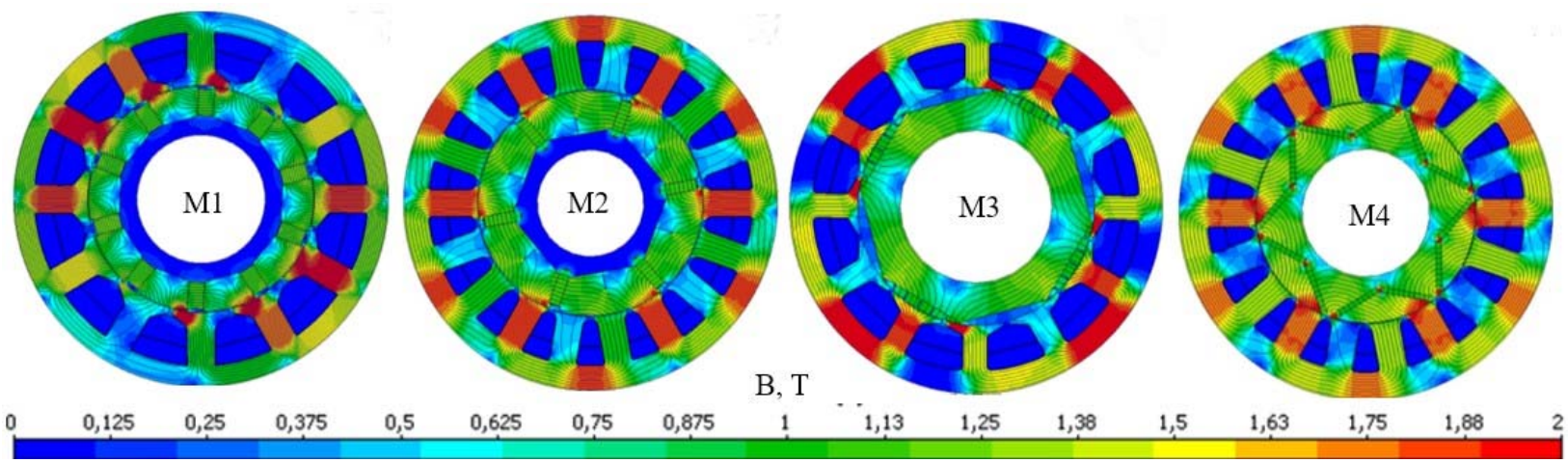

Fig. 2 
It should be noted that the considered permanent magnet motors must provide power in a wide range of speed variation: from operating to maximum. The maximum rotational speed $n=4200 \mathrm{rpm}$ is more than twice the operating speed $\mathrm{n}=1750 \mathrm{rpm}$. It is known that for permanent magnet electric motors providing a wide variation in rotational speed is a problem. In a traditional permanent magnet motor, the flux is constant and unregulated. With an increase in the rotor speed, the back-EMF induced in the stator windings also increases, which leads to a decrease in the current in the windings. Thus, the maximum speed and power of the motor are limited and depend on the parameters of the stator winding and the properties of the permanent magnets of the rotor.

The fulfillment of the condition (requirement) for regulating the speed of the electric drive in a wide range is ensured by the converter (inverter) by controlling the moments of switching the windings. The moment of switching the motor windings is determined by the advance angle between the position of the qaxis of the rotor and the middle axis of the switched winding. The value of the lead angle affects the value of the rotor magnetic flux and, accordingly, the windings back-EMF. When carrying out numerical studies, the lead angle was varied in such a way as to provide the maximum torque for a given rotor speed.

By varying the geometrical and winding parameters of each of the investigated models of electric motors, the mechanical characteristics were determined at which a given torque and power is achieved in the entire range of the rotor speed. As a result of numerical studies, promising designs of electric motors with permanent magnets were found, on the basis of which it is advisable to create a tram electric drive. The calculated characteristics of various options for electric motors are shown in Fig. 3. In Fig. 3, $a$ shows the dependences of the moment on the shaft of the electric motor, and in Fig. 3, $b$-dependence of power on the rotor speed. The characteristics are given at the rated current in the motor windings.

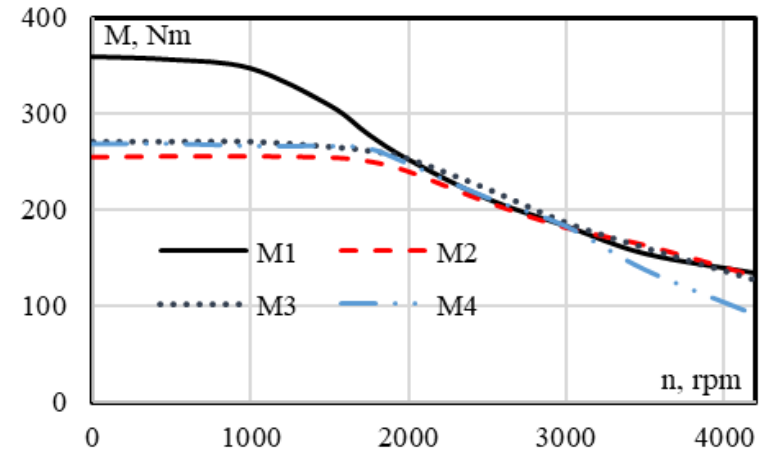

$a$

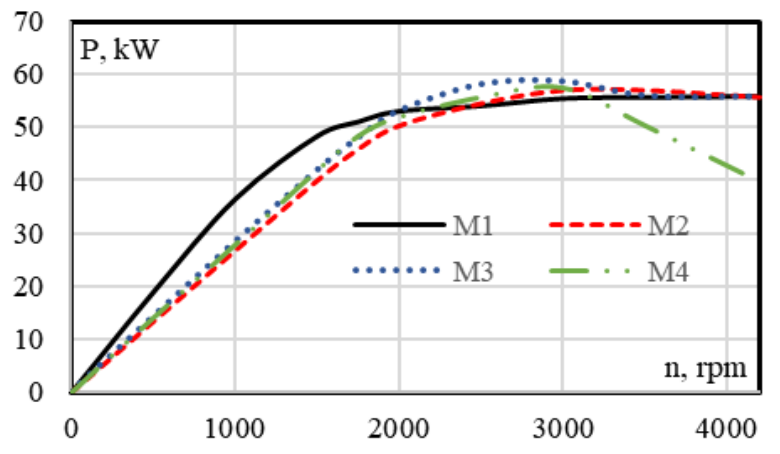

$\boldsymbol{b}$

Fig. 3

Table 1 shows the technical parameters of the investigated electric motors with permanent magnets, which can be considered as an option for replacing the existing TE-022 motor.

The main structural dimensions of the magnetic system of each version of the electric motor were obtained by performing a series of calculations taking into account the fulfillment of the basic requirements: ensuring the rated torque at rated speed and the highest possible torque at maximum speed. The calculating results of the characteristics of electric motors with permanent magnets show that the variants of electric motors M1, M3, M4 provide a given torque $(\mathrm{P} \geq 260 \mathrm{Nm})$ at a nominal speed $\mathrm{n}=1750 \mathrm{rpm}$ and for an electric motor M2 it is slightly less and is $\mathrm{P}=251 \mathrm{Nm}$. In this case, in all versions of the investigated electric motors, the current density in the windings and the magnetic induction in the stator steel are the same. All variants are brought to the same power level $(46 \div 51 \mathrm{~kW})$ by changing the motor length. With the same motor diameter and its electromagnetic loads, the motor length can be a criterion for comparing different motor options.

Numerical studies have shown that the M1 multi-pole electric motor has the greatest length of the magnetic system in comparison with other options. However, the length of the magnetic system of the M1 electric motor is significantly less than the corresponding length of the TE-022 DC motor. The result of the calculation of the M1 electric motor confirms the possibility of using a multi-pole electric motor with permanent magnets and lumped windings for a relatively high-speed drive ( $\mathrm{n}=1750 \mathrm{rpm})$. The mechanical performance of the M1 electric motor is acceptable for transport systems. The starting torque of this motor is higher than that of other electric motor options.

The calculation results for electric motors M2 and M4 confirm the prospects of these motors for 
replacing the existing TE-022 drive. The design of the motors provides for salient-poles steel rotor, which are adjoined by permanent magnets. By choosing the configuration of the pole and magnets, a large amount of magnetic flux through the pole can be achieved with a relatively low reluctance of the main magnetic circuit. The relatively low resistance of the main magnetic circuit favorably affects the ability of the control system to regulate the motor torque by changing the lead angle of the winding commutation.

Table 1

\begin{tabular}{|l|c|c|c|c|c|}
\hline & & M1 & M2 & M3 & M4 \\
\hline Poles number & & 10 & 6 & 4 & 6 \\
\hline Stator slots number & & 12 & 18 & 12 & 18 \\
\hline Number of turns & & 14 & 7 & 14 & 6 \\
\hline Stator outer diameter & $\mathrm{mm}$ & 350 & 350 & 350 & 350 \\
\hline Stator / rotor length & $\mathrm{mm}$ & $\mathbf{2 4 0}$ & $\mathbf{2 0 0}$ & $\mathbf{2 0 0}$ & $\mathbf{2 0 0}$ \\
\hline Rotor diameter & $\mathrm{mm}$ & 210 & 210 & 220 & 206 \\
\hline Air gap & $\mathrm{mm}$ & 1,0 & 1,0 & 1,0 & 1,0 \\
\hline Skew of poles on the rotor & $\mathrm{deg}$ & 30 & 20 & 30 & 20 \\
\hline Stator steel weight & $\mathrm{kg}$ & 70,6 & 68,7 & 54,6 & 73,7 \\
\hline Rotor steel weight & $\mathrm{kg}$ & 22,2 & 27,9 & 27,2 & 33,5 \\
\hline Windings (copper) weight & $\mathrm{kg}$ & 25,8 & 19,0 & 33,4 & 16,6 \\
\hline Weight of magnets & $\mathrm{kg}$ & 6,75 & 3,15 & 2,94 & 4,05 \\
\hline Total mass of the magnetic system & $\mathrm{kg}$ & 125 & 119 & 118 & 128 \\
\hline Magnetic system volume & $\mathrm{m} 3$ & 0.023 & 0.019 & 0.019 & 0.019 \\
\hline Rated voltage & $\mathrm{V}$ & 600 & 600 & 600 & 600 \\
\hline Rated current & $\mathrm{A}$ & 75 & 75 & 75 & 75 \\
\hline Current density & $\mathrm{A} / \mathrm{mm}^{2}$ & 3,83 & 4,04 & 3,95 & 3,92 \\
\hline Rated mode & & & & & \\
\hline Lead angle & $\mathrm{el.degrees}$ & 40 & 35 & 15 & 30 \\
\hline Rated speed & $\mathrm{rpm}$ & 1750 & 1750 & 1750 & 1750 \\
\hline Rated torque & $\mathrm{Nm}$ & 279 & 251 & 262 & 264 \\
\hline Rated power & $\mathrm{kW}$ & 51 & 46 & 48 & 48,4 \\
\hline Specific power & $\mathrm{kW} / \mathrm{m}^{3}$ & 2210 & 2387 & 2496 & 2517 \\
\hline Specific torque & $\mathrm{kW} / \mathrm{m}^{3}$ & 12089 & 13051 & 13623 & 13727 \\
\hline Maximum mode & & & & & \\
\hline Lead angle & $\mathrm{el.degrees}$ & 72 & 69 & 64 & 71 \\
\hline Maximum speed & $\mathrm{rpm}$ & 4200 & 4200 & 4200 & 4200 \\
\hline Torque & $\mathrm{Nm}$ & 134,1 & 127 & 127 & 84,2 \\
\hline Power & $\mathrm{kw}$ & 55,8 & 55,7 & 55,8 & 39,8 \\
\hline Start mode & & & & & \\
\hline Lead angle & $\mathrm{el} . \mathrm{degrees}$ & 0 & 10 & 10 & 30 \\
\hline Rotor speed & $\mathrm{rpm}$ & 500 & 500 & 500 & 500 \\
\hline Starting current & $\mathrm{A}$ & 200 & 200 & 200 & 200 \\
\hline Starting torque & $\mathrm{Nm}$ & 964 & 674 & 700 & 746 \\
\hline
\end{tabular}

The calculation results for the M3 electric motor with permanent magnets installed on the outer surface of the rotor show a significant effect of the number of winding turns on the mechanical characteristics of the motor. Even with a decrease in the number of poles to four, with an increase in the frequency of rotation above the nominal, back-EMF winding increases significantly and causes a decrease in current and torque. Installing magnets on the outer surface of the rotor with radial magnetization increases the reluctance of the magnetic circuit. With this configuration of the magnetic system, the ability of the control system to reduce the magnetic flux is limited. With the accepted limitation of the current density in the windings, the magnetomotive force (MDF) of the stator winding does not provide sufficient attenuation of the magnetic flux of the rotor with permanent magnets. As a result, the mechanical characteristic of the M3 electric motor at a speed higher than the rated speed does not provide the required stiffness of the characteristic. The best specific characteristics at the rated rotor speed of the M4 electric motor, however, this motor has the lowest power and torque at the maximum rotor speed $(\mathrm{n}=4200 \mathrm{rpm})$. 
The mechanical characteristics of a permanent magnet electric motor largely depend on the control system of the electric motor - the frequency converter. The maximum motor torque is determined by the maximum current that the frequency converter can supply. Calculations of all variants of electric motors with permanent magnets showed that there are no restrictions on reaching three times the rated torque. When the motor is supplied with a current of $200 \mathrm{~A}$, the voltage on the motor at start is less than the rated voltage. Accordingly, there is the possibility of further increasing the current and torque. The starting torque is limited by the cooling conditions of the winding at start.

Calculations of the variants of electric motors show that within the limits of the overall dimensions of the TE-022 DC motor, the length of the electric motors with permanent magnets can be increased. Accordingly, when the length of the permanent magnet motor is increased, a high overload capacity of the motor can be ensured as compared to the TE-022 DC motor.

Thus, the replacement of the existing TE-022 DC motor with a permanent magnet motor is a promising project to improve the efficiency and reliability of the T-3 tram.

Low speed gearless traction drive. Nowadays, the requirements for the tram have increased significantly. A modern tram must be low-floor and provide a comfortable ride for a large number of passengers. Leading tramway manufacturers are introducing a new motor bogie layout. The new layout of the bogie provides for independently rotating wheels with a traction drive, which is placed on the outer side of the wheel [11]. The use of new bogies can significantly improve the efficiency of the tram. An example of a new tram design is the Skoda FORCITY ALFA tram [12].

The cart of this tram has an individual drive for each wheel, which ensures an ideal ride both on bends and on straight sections. Traction motors are permanent magnet motors that are directly connected to the wheel without a gearbox.

The new layout of the tram bogies limits the overall dimensions of the electric motor. Permanent magnet motors are liquid cooled to generate high torque. Basic parameters of the ŠKODA ELECTRIC HLU $3436 \mathrm{P} / 44-\mathrm{VA}$ tram drive of the FORCITY ALFA tram (Czech Republic): rated moment - $1460 \mathrm{Nm}$; maximum moment $-2270 \mathrm{Nm}$; rated speed $-320 \mathrm{rpm}$; maximum rotation speed - $706 \mathrm{rpm}$; rated current $85.4 \mathrm{~A}$; electric motor weight $-252 \mathrm{~kg}$.

When studying various design options for permanent magnet electric motors, all of them must meet the specified technical requirements: torque, power, type of mechanical characteristics. The traction drive must provide a rated torque $\mathrm{M}_{\text {nom }}=1450 \mathrm{Nm}$ in continuous operation (S1). In this case, in the range from zero to the rated speed $n_{\text {nom }}=200 \mathrm{rpm}$, the torque of the electric motor must be at least the rated one. With a further increase in the speed to the maximum value $\mathrm{n}_{\max }=700 \mathrm{rpm}$, the power of the electric motor must be at least $\mathrm{P}_{\text {nom }}=46 \mathrm{~kW}$. Also, the electric motor must provide a maximum torque $\mathrm{M}_{\max }=2270 \mathrm{Nm}$ in short-term duty (S5).

For these initial data, four variants of the configuration of the magnetic system were also investigated. All variants of permanent magnet motors have the same outer diameter of the magnet system. Also, for all variants, the same electromagnetic loads (current density, magnetic induction value in the stator teeth) are set. A general view of the design variants of the investigated electric motors with permanent magnets is shown in Fig. 4.

The relatively low rotor speed, not more than $n_{\max }=700 \mathrm{rpm}$, allows the use of a larger number of poles than for M1-M4 electric motors. For the M7 electric motor, the magnets are not divided into parts, since at a low rotor speed; the effect of eddy currents is not significant.

Magnetic field patterns for the nominal mode of each of the options are shown in Fig. 5. Analyzing the calculation results, it should be noted that the maximum magnetic induction in the teeth of the investigated electric motors is as follows: M5-- BM5 (tooth) $=1.94$ T; M6 - BM6 (tooth) $=2.0$ T; M7 - BM7 (tooth) $=1.82 \mathrm{~T}$; M8 - BM8 (tooth) $=1.96 \mathrm{~T}$. In the back of the stator, the maximum values of magnetic induction are as follows: M5 - BM5 (back)=1.14 T; M6 - BM6 (back)=2.0 T; M7 - BM7 (back)=1.73 T; M8 - BM8 (back) $=1.98 \mathrm{~T}$. For low-speed motors, the condition is also fulfilled that the induction in the teeth and back of the stator is limited to $\mathrm{B}=2.0 \mathrm{~T}$.

Calculations of variants for low-speed gearless traction motors with permanent magnets showed that the main parameter that determines the motor torque is the current density in the windings. The design of the permanent magnet motor allows high current densities in the windings. The presence of permanent magnets and the associated high resistance of the magnetic circuit practically exclude saturation of the stator steel at high currents. As a result, the torque is limited by the permissible current load of the motor windings. With liquid cooling of an electric motor with permanent magnets, the current density in the windings can reach 
values up to $20 \mathrm{~A} / \mathrm{mm}^{2}$, which ensures high specific indicators of the motor (the ratio of the torque to the mass of the motor).

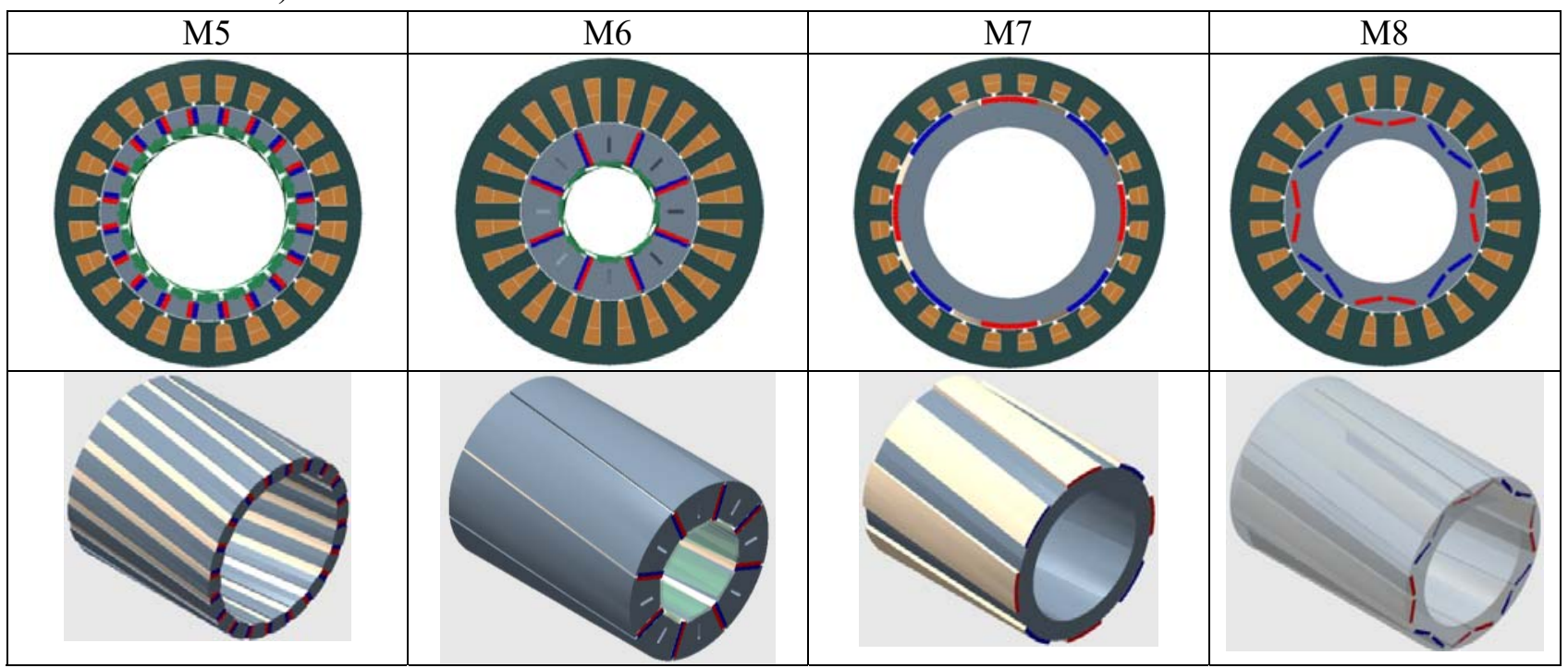

Fig. 4

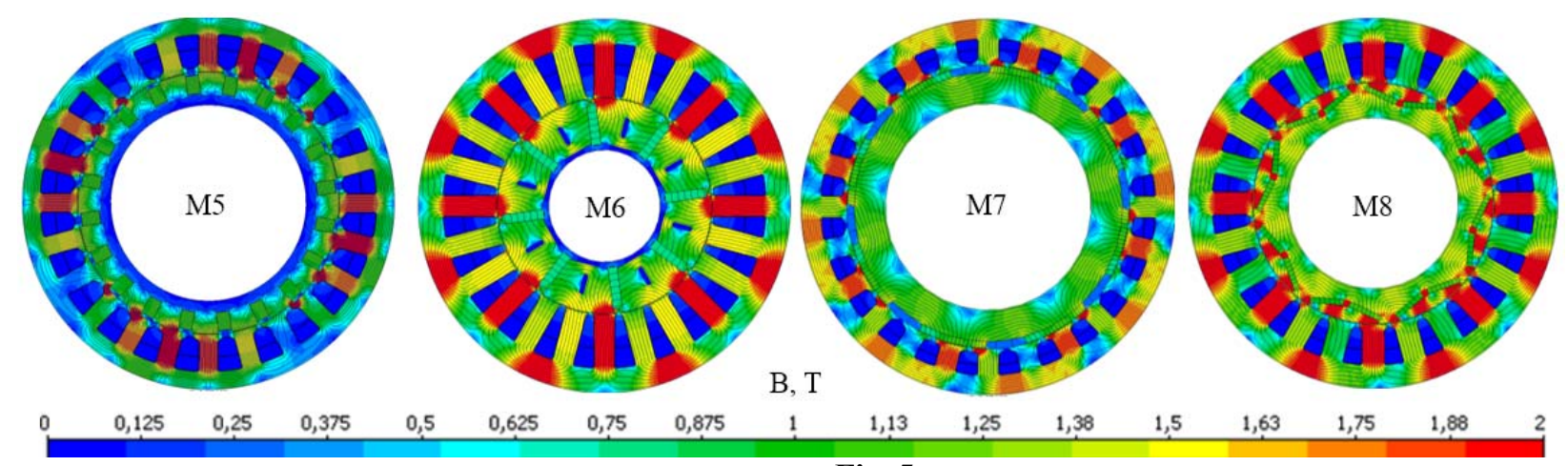

Fig. 5

When performing calculations of various variants for electric motors with permanent magnets, the current density in the windings was taken equal to $10 \mathrm{~A} / \mathrm{mm}^{2}$. At a given current density, the specified torque of the electric motor was ensured with its limited dimensions (outer diameter, length). The length of the electric motors in the various variants is from 280 to $335 \mathrm{~mm}$.

By varying the geometrical and winding parameters for each of the investigated models of electric motors, the mechanical characteristics are determined at which a given torque is achieved at a nominal speed $\mathrm{n}=320 \mathrm{rpm}$ and the maximum possible torque is provided with an increase in the rotational speed to $\mathrm{n}=700 \mathrm{rpm}$. The calculated characteristics of various options for electric motors are shown in Fig. 6. In Fig. 6, $a$ shows the dependences of the moment on the shaft of the electric motor, and in Fig. $6, b$-dependence of power on the rotor speed. The characteristics of the electric motors are given at the rated current of the electric motor.

Table 2 shows the technical parameters of the investigated electric motors with permanent magnets. When analyzing various design options for permanent magnet electric motors, options M5, M6 and M8 should be highlighted, these options provide rated power in a wide range of rotor speed variation: from nominal to maximum. The multi-pole design of the rotor allows the control system to fully regulate the magnetic flux of the motor at maximum speed.

The variant of the M5 electric motor has the best specific performance at the rated speed. The presence of a large number of rotor poles $\mathrm{N}=20$, when using modern control methods, does not negatively affect the characteristics of the motor. 

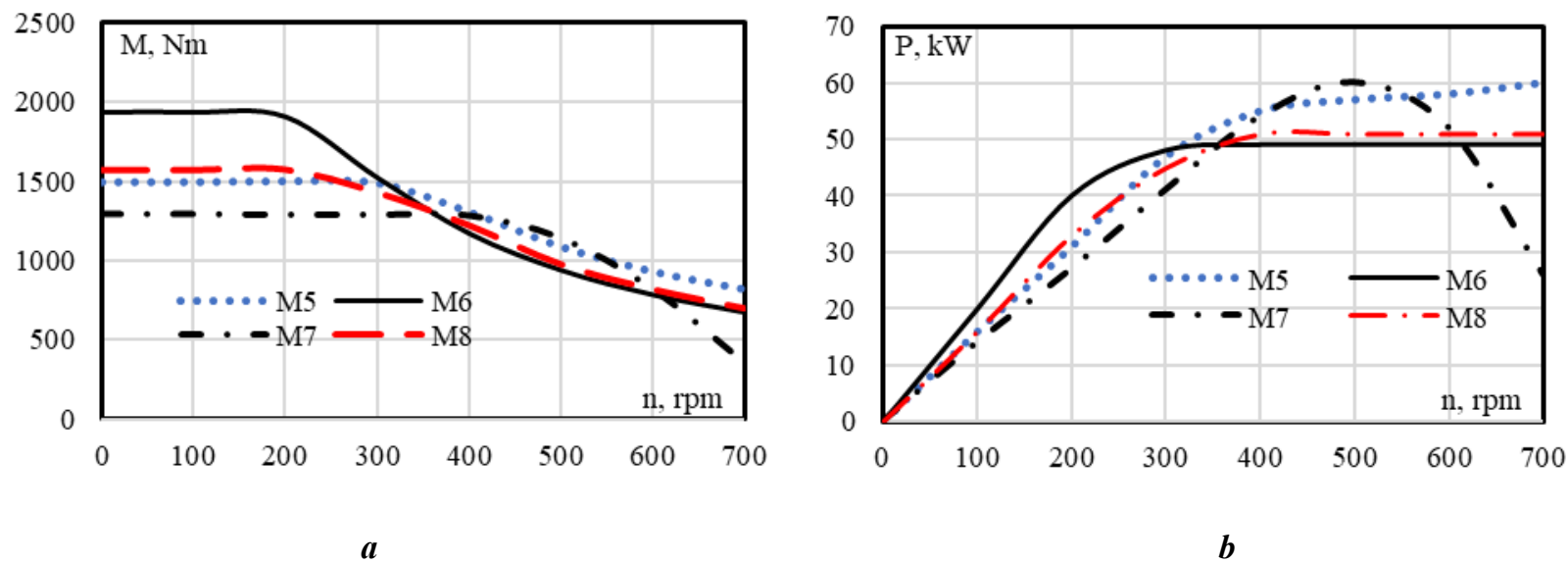

Fig. 6

The M7 variant does not provide the specified power at the maximum speed. In this case, the control system does not provide a decrease in the back-EMF stator windings at increased rotor speed. The variant of the M7 electric motor is inferior in terms of weight and dimensions at the rated rotor speed in comparison with other options. For the M7 electric motor, the specific characteristics (power and torque referred to the volume of the electric motor) at the rated speed are the worst.

Table 2

\begin{tabular}{|c|c|c|c|c|c|}
\hline & & M5 & M6 & M7 & M8 \\
\hline Poles number & & 20 & 8 & 8 & 8 \\
\hline Stator slots number & & 24 & 24 & 24 & 24 \\
\hline Number of turns & & 14 & 16 & 9 & 12 \\
\hline Stator outer diameter & $\mathrm{mm}$ & 400 & 400 & 400 & 400 \\
\hline Stator / rotor length & $\mathrm{mm}$ & 280 & 300 & 325 & 335 \\
\hline Rotor diameter & $\mathrm{mm}$ & 280 & 230 & 300 & 260 \\
\hline Center hole diameter & $\mathrm{mm}$ & 210 & 120 & 220 & 185 \\
\hline Air gap & $\mathrm{mm}$ & 1,0 & 1,0 & 1,0 & 1,0 \\
\hline Stator steel weight & $\mathrm{Kg}$ & 93,6 & 141 & 103 & 143 \\
\hline Rotor steel weight & $\mathrm{Kg}$ & 27,7 & 53,8 & 65,2 & 67,2 \\
\hline Windings (copper) weight & $\mathrm{Kg}$ & 23,1 & 33 & 19,7 & 25,1 \\
\hline Weight of magnets & $\mathrm{Kg}$ & 11,8 & 8,25 & 10,0 & 8,68 \\
\hline Total system weight & $\mathrm{Kg}$ & 156 & 236 & 197 & 244 \\
\hline Magnetic system volume & $\mathrm{m}^{3}$ & 0.0352 & 0.0377 & 0.0408 & 0.0421 \\
\hline Rated current & A & 85 & 85 & 85 & 85 \\
\hline Current density & $\mathrm{A} / \mathrm{mm}^{2}$ & 9,89 & 9,97 & 10,10 & 10,5 \\
\hline \multicolumn{6}{|l|}{ Rated mode } \\
\hline Lead angle & el.degrees & 11 & 18 & 5 & 43 \\
\hline Rated speed & $\mathrm{rpm}$ & 320 & 320 & 320 & 320 \\
\hline Rated torque & $\mathrm{Nm}$ & 1480 & 1470 & 1290 & 1480 \\
\hline Rated power & $\mathrm{kW}$ & 50 & 49 & 45 & 46 \\
\hline Specific power & $\mathrm{kW} / \mathrm{m}^{3}$ & 1420 & 1300 & 1078 & 1093 \\
\hline Specific torque & $\mathrm{Nm} / \mathrm{m}^{3}$ & 42045 & 38992 & 31618 & 35154 \\
\hline \multicolumn{6}{|l|}{ Maximum mode } \\
\hline Lead angle & el.degrees & 58 & 75 & 67 & 77 \\
\hline Maximum speed & $\mathrm{rpm}$ & 700 & 700 & 700 & 700 \\
\hline Torque & $\mathrm{Nm}$ & 820 & 670 & 359 & 694 \\
\hline Power & $\mathrm{kw}$ & 50 & 49 & 26 & 51 \\
\hline \multicolumn{6}{|l|}{ Start mode } \\
\hline Lead angle & el.degrees & 0 & 10 & 10 & 30 \\
\hline Starting current & $\mathrm{A}$ & 212 & 212 & 212 & 212 \\
\hline Starting torque & $\mathrm{Nm}$ & 3747 & 4686 & 3192 & 3236 \\
\hline
\end{tabular}


Heating calculation of the investigated electric motors. As a result of a number of calculations, by varying the geometric parameters of the magnetic system of electric motors, the optimal ratios between the outer and inner diameters of the rotor, as well as the main dimensions of the magnetic system, providing the required value of the electromagnetic moment in a given range of rotation frequency $(\mathrm{n}=0 \div 4200 \mathrm{rpm}$ for highspeed and $\mathrm{n}=0 \div 750 \mathrm{rpm}$ - low-speed tram drive). It should be noted that for a high-speed drive, air cooling is used by a fan; for a low-speed gearless drive, a high value of the electromagnetic torque for a given materials (permanent magnets, windings, stator and rotor iron) did not exceed the permissible values. Therefore, it is necessary to perform a thermal calculation of electric motors taking into account the urban driving cycle, which describes the movement of a vehicle in the city (engine operation at minimum speed, starting and accelerating to a certain speed, engine braking from one speed to another, parking) [3]. When performing thermal calculations, the study was carried out for the cycles of tram movement, which are given in Table 3 .

Table 3

\begin{tabular}{|l|c|c|c|c|c|c|c|}
\hline & & \multicolumn{3}{|c|}{ M1-M4 } & \multicolumn{3}{c|}{ M5-M8 } \\
\hline Interval & $\begin{array}{c}\text { Duration } \\
(\mathrm{sec})\end{array}$ & $\begin{array}{c}\text { Torque } \\
(\mathrm{Nm})\end{array}$ & $\begin{array}{c}\text { Start Speed } \\
(\mathrm{rpm})\end{array}$ & $\begin{array}{c}\text { End Speed } \\
(\mathrm{rpm})\end{array}$ & $\begin{array}{c}\text { Torque } \\
(\mathrm{Nm})\end{array}$ & $\begin{array}{c}\text { Start Speed } \\
(\mathrm{rpm})\end{array}$ & $\begin{array}{c}\text { End Speed } \\
(\mathrm{rpm})\end{array}$ \\
\hline 1 (overclocking) & 14 & 650 & 0 & 500 & 2300 & 0 & 200 \\
\hline 2 (motion) & 80 & 260 & 500 & 4200 & 1500 & 200 & 700 \\
\hline 3 (free moving) & 26 & 0 & 4200 & 1750 & 0 & 700 & 320 \\
\hline 4 (braking) & 10 & -200 & 1750 & 0 & -2000 & 320 & 0 \\
\hline 5 (parking) & 15 & 0 & 0 & 0 & 0 & 0 & 0 \\
\hline
\end{tabular}

The calculation of the temperature of electric motors M1-M4 was carried out in the Infolytica MotorSolve package [13], taking into account the driving cycle and air cooling by fan. The flow rate of the

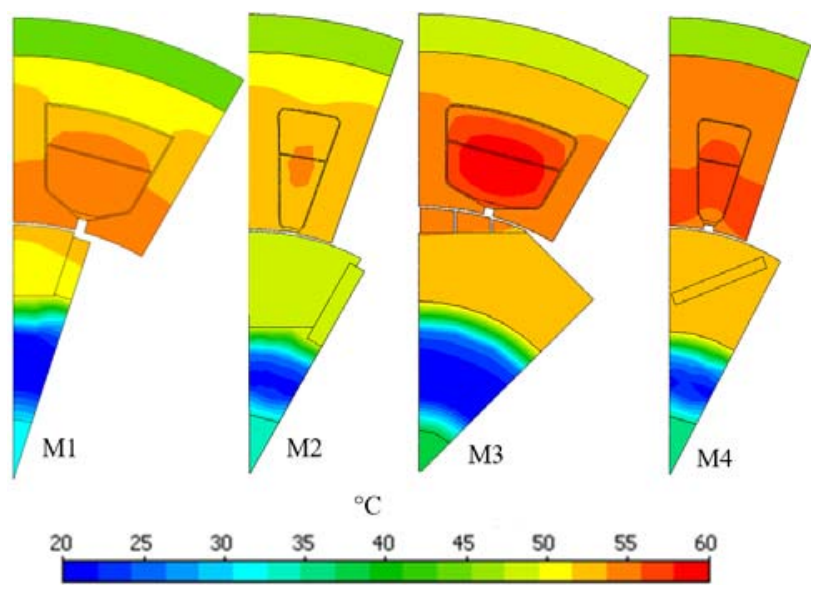

Fig. 7 cooled air was set equal to $3 \mathrm{~m} / \mathrm{s}$. In Fig. 7 shows the picture of the thermal field for electric motors $\mathrm{M} 1 \div \mathrm{M} 4$. According to the results of the thermal calculation, all parts of the electric motors do not heat up above $60^{\circ} \mathrm{C}$. The calculation of the temperature of the investigated electric motors M5-M8 was carried out in the Infolytica MotorSolve package [13], taking into account liquid cooling. The cooling system is a series of channels evenly spaced along the entire outer surface of the electric motor housing and oriented along the axis of rotation of the electric motor. A coolant (water) is pumped through these channels with the help of a circulation pump at a predetermined speed and a predetermined initial

temperature. Moving through the channels of the cooling system, the coolant takes away the heat generated by the windings of the electric motor.

Initial data for thermal calculation are as follows: number of cooling channels $-\mathrm{N}_{\mathrm{c}}=120$; the shape of the cooling channels is round; diameter of the cooling channels $d_{c}=8 \mathrm{~mm}$; the initial temperature at the inlet to the cooling channels is $40^{\circ} \mathrm{C}$, the capacity of the circulation pump is $\mathrm{Q}=31 / \mathrm{min}$. Fig. $8, a$ shows a picture of the thermal field of M6 $\div$ M8 electric motors with liquid cooling, from which it follows that all parts of the electric motors do not heat up above the permissible temperature (the maximum heating temperature of the $\mathrm{M} 6$ motor windings is $120^{\circ} \mathrm{C}$, for magnets $-110{ }^{\circ} \mathrm{C}$ (the temperature stability of the $\mathrm{N} 45 \mathrm{SH}$ magnets is $150^{\circ} \mathrm{C}$ ). It should be noted that without liquid cooling, the windings and magnets heat up above the permissible temperature. This is demonstrated by the graphs shown in Fig. 8, $b$. From these graphs it follows that in the absence of liquid cooling, the heating temperature of the magnets after 240 minutes of engine operation is $170^{\circ} \mathrm{C}$, and the windings $-200^{\circ} \mathrm{C}$, which is not permissible and would lead to the exit of the motor from the side.

\section{Conclusions.}

1. Numerical research and comparative analysis of various variants of magnetic systems of electric motors with permanent magnets shows the fundamental possibility of creating on their basis, both traditional (high-speed) and gearless (low-speed) traction electric tram drive. 
2. A comparative analysis of various options for permanent magnet electric motors was carried out on condition that the motors were connected to a sinusoidal current source and optimal regulation was ensured by changing the moment of switching the windings (lead angle). This power supply mode for electric motors can be provided by modern power converters with vector control.

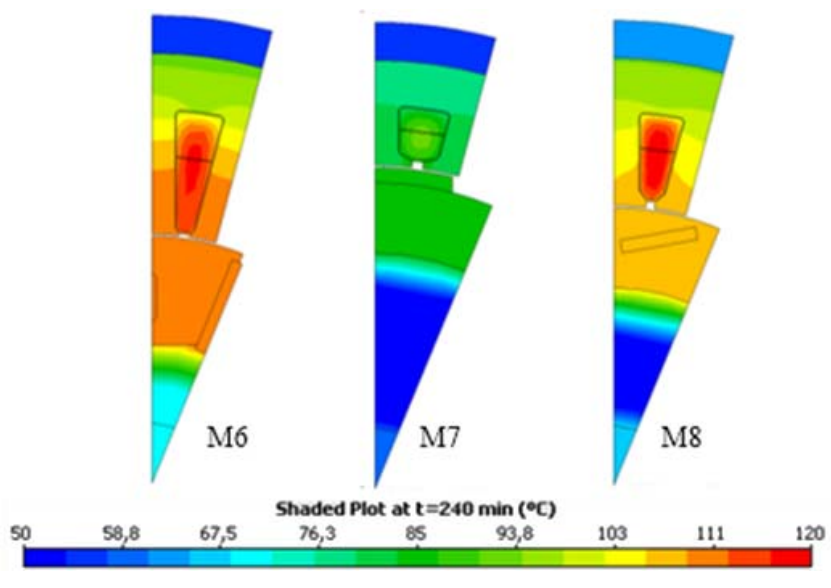

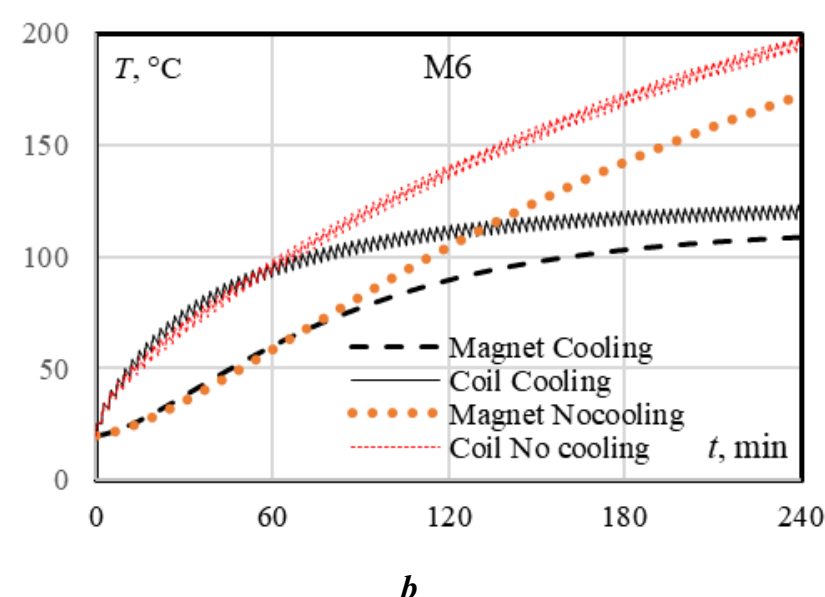

$b$

Fig. 8

3. Research have shown that all variants of high-speed electric motors with permanent magnets M1, M2, M3, M4 are competitive with the existing TE-022 DC electric motor and can be promising as its replacement as one of the options for increasing the efficiency and reliability of the T3 tram. The M4 electric motor has the best specific characteristics at the nominal rotor speed; however, this motor has the lowest power and torque at the maximum rotor speed $(n=4200 \mathrm{rpm})$, therefore the most promising options are M2 and $\mathrm{M} 3$, since the mass of permanent magnets in these options is the smallest.

4. For a low-speed gearless tram drive of a new generation, variants of electric motors with permanent magnets M5, M6, M8 are the most promising. The M7 motor version has the best specific performance at the rated speed. This variant has the largest number of stator poles compared to other variants.

5. Thermal calculation of the investigated electric motors, carried out taking into account the driving cycle, showed that for a high-speed electric drive, all parts of the electric motors do not heat up above $60^{\circ} \mathrm{C}$ when air cooled with a fan. For a low-speed gearless drive with liquid cooling, all parts of the electric motors do not heat up above the permissible temperature (the maximum heating temperature of the windings is $120^{\circ} \mathrm{C}$, for the magnets $-110^{\circ} \mathrm{C}$ (the temperature stability of the $\mathrm{N} 45 \mathrm{SH}$ magnets is $150^{\circ} \mathrm{C}$ ).

Роботу виконано за держбюджетною темою «Розвиток наукових основ і розробка принципів побудови електромеханічних перетворювачів енергії з постійними магнітами та магнітними редукторами», (иифр «МАГРЕД»), КПКВК 6541030.

1. Ivanov M.D., Ponomarev A.A., Ieropol'skij B.K. Tram cars T-3. Moskva: Transport, 1977. 240 p. (Rus)

2. Volkov V.A. Optimization of electric consumption of trolleybus with traction frequency-regulated asynchronous engine and super-condensating driver of generated energy. Elektromekhanichni i energozberigayuchi sistemi. 2019. Vypusk 1(45). Pp. 87-103. (Rus)

3. Peresada S.M., Kovbasa S.N., Bovkunovich V.S. Comparative testing of algorithms for vector and frequency control of the torque of an induction motor in electromechanical systems of passenger electric transport. Visnik Kremenchuc'kogo derzhavnogo politekhnichnogo universitetu imeni Mihajla Ostrograds'kogo. 2009. Vypusk 4 (57), ch. 1. Pp. 13-16. DOI: https://doi.org/ela.kpi.ua/handle/123456789/38973. (Rus)

4. Zakharov A., Kobelev A., Makarov L., Skitovich S. Research, Development, Manufacturing and Application of Energy Efficient Electric Motors. X International Conference on Electrical Power Drive Systems (ICEPDS). 2018. Novocherkassk, Russia, October 3-6, 2018. Pp. 1-6. DOI: https://doi.org/10.1109/ICEPDS.2018.8571692 .

5. Tergemes K.T., Amangaliyev Y.Z., Karassayeva A.R. Perspective Directions of the Development of Electric Transports' Electric Drive. International Multi-Conference on Industrial Engineering and Modern Technologies (FarEastCon). 2019. Vladivostok, Russia, October 1-4, 2019. Pp. 1-5.

DOI: https://doi.org/10.1109/FarEastCon.2019.8934792 . 
6. Traction converters. URL: www.abb.com/tractionconverters (accessed: 16.05.2021)

7. Vaskovskyi Yu.M., Haidenko Yu.A., Rusiatynskyi A.E. Mathematical modeling and selecting of construction parameters for traction synchronous motors with permanent magnets. Tekhnichna elektrodinamika. 2013. No 6. Pp. 4045. (Rus)

8. Huynh T.A, Hsieh M-F. Performance Analysis of Permanent Magnet Motors for Electric Vehicles (EV) Traction Considering Driving Cycles. Energies. 2018. Vol. 11(6): 1385. DOI: https://doi.org/10.3390/en11061385 9 .

9. Ehab Sayed, Rong Yang, Jianbin Liang, Mohamed H. Bakr, Berker Bilgin, Ali Emadi. Design of unscrewed interior permanent magnet traction motor with asymmetric flux barriers and shifted magnets for electric vehicles. Electric Power Components and Systems. 2020. Vol. 48. No 6-7. Pp. 652-657. DOI: https://doi.org/10.1080/15325008.2020.1797938

10. Grebenikov V.V., Priymak M.V. Methods for reducing the pulsations of the electromagnetic moment in electric machines with permanent magnets of tangential magnetization. Visnik Natsionalnoho tekhnichnoho universitetu KhPI. 2014. Vypusk 38. Seriya: Elektrichni mashini ta elektromekhanichne peretvorennya energii. Pp. 69 - 78. (Rus)

11. Nikitin V.V., Parmas A.YA.-YU., Pivovarov V.M., Sattarov R.R. Gearless traction electric drive of urban rail transport. Izvestiya PGUPS. Sovremennye tekhnologii-transportu. 2013. No 1. Pp. 31-38. (Rus)

12. Tram «Forcity Alfa» Praga. URL: www.skoda.cz/ru/references/tramcar-forcity-alfa-prague (accessed: 16.05.2021) (Rus)

13. Simcentre Motorsolve URL: https://www.infologicdesign.co.uk/motorsolve (accessed: 16.05.2021)

\section{ПОРІВНЯЛЬНИЙ АНАЛІЗ МАГНІТНИХ СИСТЕМ ЕЛЕКТРОДВИГУНІВ З ПОСТІЙНИМИ МАГНІТАМИ ДЛЯ ТРАМВАЯ}

В.В. Гребеніков*, докт. техн. наук, Р.В. Гамалія**, канд. фіз.-мат. наук, С.А. Дадичін Інститут електродинаміки НАН України, пр. Перемоги, 56, Київ, 03057, Україна, e-mail: elm1153@gmail.com

Проведено чисельне дослідження восьми конфігурацій магнітної систем електродвигунів з постійними магнітами для приводу трамвая. Електродвигун з постійними магнітами може бути використаний як високошвидкісний для заміни існуючого електроприводу постійного струму трамвая, а також як низькошвидкісний безредукторний електропривод трамвая нового покоління. Визначено найбільш перспективні конфігураиії магнітних систем з постійними магнітами для приводу трамвая. Шляхом варіації геометричних $i$ обмотувальних параметрів кожної з досліджуваних моделей електродвигунів, визначено механічні характеристики, за яких досягається заданий момент і потужність у всьому діапазоні частоти обертання ротора. Також виконано тепловий розрахунок з урахуванням міського їздового ичиклу високошвидкісних двигунів у разі повітряного охолодження вентилятором $i$ низькошвидкісних - в режимі рідинного охолодження. Розрахунок характеристик досліджуваних електродвигунів виконаний у програмному пакеті Simcentre MotorSolve. Бібл. 13, рис. 8, табл. 3

Ключові слова: чисельне моделювання, електродвигун, постійні магніти, електромагнітний момент, робочі характеристики, тепловий розрахунок, електропривод трамвая.

Надійшла 24.05.2021 